\title{
Flourishing in trying circumstances: A hermeneutic phenomenological exploration of volunteer well-being
}

\begin{tabular}{|c|c|}
\hline \multicolumn{2}{|c|}{$\begin{array}{l}\text { Authors: } \\
\text { Aleksandra Furtak }^{1} \\
\text { Antoni Barnard }^{2}\end{array}$} \\
\hline \multicolumn{2}{|c|}{$\begin{array}{l}\text { Affiliations: } \\
{ }^{1} \text { Department of Human } \\
\text { Resource Management, } \\
\text { Faculty Economic and } \\
\text { Management Sciences, } \\
\text { University of South Africa, } \\
\text { Pretoria, South Africa }\end{array}$} \\
\hline \multicolumn{2}{|c|}{$\begin{array}{l}{ }^{2} \text { Department Industrial and } \\
\text { Organisational Psychology, } \\
\text { Faculty Economic and } \\
\text { Management Sciences, } \\
\text { University of South Africa, } \\
\text { Pretoria, South Africa }\end{array}$} \\
\hline \multicolumn{2}{|c|}{$\begin{array}{l}\text { Corresponding author: } \\
\text { Aleksandra Furtak, } \\
\text { hyraam@unisa.ac.za }\end{array}$} \\
\hline \multicolumn{2}{|c|}{$\begin{array}{l}\text { Received: } 14 \text { May } 2020 \\
\text { Accepted: } 20 \text { Oct. } 2020 \\
\text { Published: } 22 \text { Jan. } 2021\end{array}$} \\
\hline \multicolumn{2}{|c|}{$\begin{array}{l}\text { How to cite this article: } \\
\text { Furtak, A., \& Barnard, A. } \\
\text { (2021). Flourishing in trying } \\
\text { circumstances: A hermeneutic } \\
\text { phenomenological exploration } \\
\text { of volunteer well-being. } \\
\text { SA Journal of Industrial } \\
\text { Psychology/SA Tydskrif vir } \\
\text { Bedryfsielkunde, } 47(0) \text {, a1809. } \\
\text { https://doi.org/10.4102/sajip. } \\
\text { v47i0.1809 }\end{array}$} \\
\hline \multicolumn{2}{|c|}{$\begin{array}{l}\text { Copyright: } \\
\text { (c) 2021. The Authors. } \\
\text { Licensee: AOSIS. This } \\
\text { is licensed under the } \\
\text { Creative Commons } \\
\text { Attribution License. }\end{array}$} \\
\hline \multirow[b]{2}{*}{ 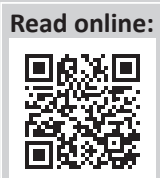 } & \\
\hline & $\begin{array}{l}\text { Scan this } Q R \\
\text { code with your } \\
\text { smart phone or } \\
\text { mobile device } \\
\text { to read online. }\end{array}$ \\
\hline
\end{tabular}

Orientation: Owing to the reliance on volunteer labour for their success, the behaviour and attitudes of volunteers is of central concern to non-profit organisations (NPOs). To optimise volunteer functioning and retention in a unique and challenging work context, it is necessary to understand their well-being.

Research purpose: The objective of this study was to explore the work-life experiences of volunteers to better understand the manifestations of well-being in the volunteering work context.

Motivation for the study: Because of the unique and challenging work setting that constitutes volunteering, and the important contribution volunteers make to society and the economy, research is needed from an industrial and organisational psychology (IOP) perspective on the well-being of volunteers.

Research approach/design and method: This study was directed by a hermeneutic phenomenological methodology. Eight volunteers from an NPO operating in the South African provincial health sector participated in in-depth interviews. The data obtained were analysed using a six-stage theoretical thematic analytical process.

Main findings: Guided by 'flourishing at work' as the theoretical framework, four themes were co-constructed from the data: learning and growing in competence, demonstrating an engaged state of mind, exhibiting emotional well-being and feeling socially integrated and connected.

Practical/managerial implications: The results of this study may assist NPOs in developing context-specific interventions aimed at managing and enhancing well-being in volunteers.

Contribution/value-add: This study contributes to the body of knowledge on the well-being of volunteers, who are considered a distinct workforce in the field of IOP.

Keywords: volunteer; well-being; flourishing; industrial and organisational psychology; hermeneutic phenomenology; qualitative.

\section{Introduction}

Well-being is important for employers and employees alike (Kowalski \& Loretto, 2017). In view of its influence on outcomes such as job satisfaction, positive working relationships, productivity and performance, it is in the best interests of organisations to focus on well-being (Kowalski \& Loretto, 2017; Kun \& Gadanecz, 2019; Roemer \& Harris, 2018; Theobald \& Cooper, 2012). For employees, higher levels of well-being result in lower levels of burnout and increased cooperation, coping abilities and prosocial behaviour (Kun \& Gadanecz, 2019). The well-being of volunteers is of particular importance because of the vital role they play in society (Mellor et al., 2008), the challenging work environments they are faced with and the dependence of voluntary organisations on volunteer labour (Boezeman \& Ellemers, 2009; Garner \& Garner, 2011; Handy \& Mook, 2011).

Volunteering is an essential phenomenon in any society owing to its positive socio-economic impact (Carter Kahl, 2019; Haski-Leventha, Hustinx, \& Handy, 2011; Manetti, Bellucci, Como, \& Bagnoli, 2015). Moreover, in the hospital environment volunteering has cost-saving, labour resource and service expansion benefits (Lourens \& Daniels-Felix, 2017). Volunteers commit their personal time, energy and effort (Clary et al., 1998) to benefit others (Penner, 2002). Volunteering is a planned, freely chosen, long-term activity that is conducted without the expectations of reward and occurs in formal organisations (Penner, 2002; Snyder \& Omoto, 2008). Volunteers represent a distinct workforce as they are motivated by altruism, and are not remunerated for 
their involvement (Fallon \& Rice, 2015). They often work under emotionally challenging circumstances (Crook, Weir, Willms, \& Egdorf, 2006) especially in the hospital environment (Folwell \& Kauer, 2018). In addition, volunteers from lowincome countries such as South Africa frequently encounter trying personal and socio-economic constraints (Kiyange, 2018; MacKenzie, Baadjies, \& Seedat, 2015).

Quantitative research about the well-being of volunteers has focused on how volunteering contributes to and promotes enhanced feelings of well-being in general (McMunn, Nazroo, Wahrendorf, Breeze, \& Zaninotto, 2009; Mellor et al., 2008; Son \& Wilson, 2012; Tabassum, Mohan, \& Smith, 2016; Thoits \& Hewitt, 2001; Van Willigen, 2000; Vecina \& Fernando, 2013) in later life (e.g., Hao, 2008; Haski-Leventhal, 2009; Morrow-Howell, Hinterlong, Rozario, \& Tang, 2003; Russell, Nyame-Mensah, De Wit, \& Handy, 2018), and the direct relation between the number of hours volunteered and well-being (Windsor, Anstey, \& Rodgers, 2008). Qualitative research related to the well-being of volunteers has focused on understanding how volunteering affects their well-being (Black \& Living, 2004; Brunier, Graydon, Rothman, Sherman, \& Liadsky, 2002; Elias, Sudhir, \& Mehrotra, 2016; Messias, De Jong, \& McLoughlin, 2005; Newman, Vasudev, \& Onawola, 1985). These studies were conducted amongst American, Canadian, European, Indian and Australian volunteers. There is, however, a lack of research on the well-being of volunteers in South Africa, and notably so from an industrial and organisational psychology (IOP) perspective. This is of concern, considering the need for research about volunteers in and from non-Western, African contexts who are affected by individual, institutional and system related challenges such as poverty, inadequate training and support, funding and financial constraints, transport difficulties and lack of policy frameworks to manage volunteers (Kiyange, 2018; VSO \& RAISA, 2011). This is true in the South African context, where many volunteers also come from less privileged socio-economic backgrounds (Barnard \& Furtak, 2020). Industrial and organisational psychology furthermore contributes to understanding the psychosocial well-being and performance of employees in the organisational context (Coetzee, 2019; Van Vuuren, 2010), offering a valuable yet unexploited disciplinary perspective for studying volunteer well-being.

Although the well-being of employees has been emphasised as being imperative for organisations, IOP research on wellbeing in the workplace has predominantly focused on paid employees (Coetzer \& Rothmann, 2007; Kheswa, 2019; Roemer \& Harris, 2018; Rothmann \& Malan, 2011). The discipline of IOP is nevertheless equally applicable to unpaid work, as volunteer workers associated with formal organisations are likely to experience stress and dissatisfaction, which may consequently have an impact on their tenure and retention (Huynh, Metzer, \& Winefield, 2012). The economic and social contribution that volunteers make to society (Haivas, Hofmans, \& Pepermans, 2013) and the dependence of non-profit organisations (NPOs) on volunteer labour underscores the importance of ensuring their optimal functioning, well-being and retention. Volunteering also presents itself as a unique field of study for industrial and organisational (IO) practitioners owing to the distinct organisational context (Boezeman \& Ellemers, 2009). As volunteering is considered an altruistic activity, volunteers are not concerned with financial security and advancement opportunities and could leave at any time (Fallon \& Rice, 2015); still, these organisations rely on volunteers for their performance and success. The behaviour, attitudes, satisfaction, turnover intentions and work engagement of volunteers are therefore of central concern to NPOs (Garner \& Garner, 2011; Haivas et al., 2013; Huynh et al., 2012) and to optimise volunteer functioning and retention, it is necessary to better understand their well-being. As the discipline of IOP is concerned with both organisational health and employee wellness (Van Vuuren, 2010) in the context of volunteering, IOP offers a valuable approach to understanding the wellbeing of volunteers for the benefit of the individual volunteer, the success of the organisation and society at large.

\section{Research motivation, objective and contribution}

The researchers were motivated to conduct this study by the importance of volunteer well-being, the unique and challenging work setting that constitutes volunteering and a lack of studies exploring the well-being of the volunteer in the field of IOP. To contribute to the body of knowledge on managing the optimal functioning and retention of volunteers, the objective of this study was to explore the work-life experiences of volunteers to delve deeper into the understanding of how volunteer well-being manifests itself in a volunteering-work context.

\section{Theoretical framework}

Research on well-being has increased to encompass a range of disciplinary fields (Fleuret \& Atkinson, 2007). This can be attributed to its relationship to desirable outcomes such as productivity and good relationships (Huppert \& So, 2013). Well-being is considered beneficial for individuals and society and makes financial sense for organisations as employees with high levels of well-being and positive functioning are considered valuable assets (Cooper \& Dewe, 2008; Roemer \& Harris, 2018). Research on well-being is typically conducted from two different perspectives, namely hedonia and eudaimonia (Deci \& Ryan, 2008; Kashdan, Biswas-Diener, \& King, 2008). As a philosophy, hedonia focuses on outcomes such as happiness and the attainment of positive affect. Eudaimonia on the other hand takes a process approach, focusing on the content of one's life and is conceived as a way of living, in other words realising one's full potential (Deci \& Ryan, 2008; Ryan, Huta, \& Deci, 2008). Although these philosophies have provided researchers with a common language for well-being (Kashdan et al., 2008), many scholars (e.g. Fleuret \& Atkinson, 2007; Huppert \& So, 2013; La Placa, McNaught, \& Knight, 2013) are of the view that well-being is dynamic, complex and multidimensional. 
This view is supported by the abundance of integrated well-being conceptualisations that have emerged, such as Keyes' (2002) model of mental health, Seligman's (2011) positive emotion, engagement, relationships, meaning, and accomplishment (PERMA) model and Rothmann's (2013) flourishing at work framework, which comprise both hedonic and eudaimonic well-being components (Henderson \& Knight, 2012). Given the plethora of conceptualisations and operational models of well-being, it is important to specify how well-being was defined and conceptualised in this study. In the present study, wellbeing was conceptualised as a multidimensional concept, explored specifically in the work context. Therefore, the flourishing at work framework which was extended by Rothmann (2013) into the South African work context was deemed relevant for addressing the objective of this study. Flourishing at work conceptualises well-being in terms of psychological, emotional and social well-being.

\section{Flourishing at work}

According to Keyes (2002), flourishing is a state encompassing high levels of well-being. Flourishing individuals experience positive feelings and positive functioning (Keyes, 2002; Wissing, Potgieter, Guse, Khumalo, \& Nel, 2020). Recognising that flourishing is highly relevant for organisational contexts, as individuals spend a large part of their adult life at work and because organisations are starting to value the strategic importance thereof, Rothmann (2013) extended the flourishing framework into this context. Rothmann (2013) conceptualises employee flourishing as consisting of three dimensions, which together capture the nature and attainment of flourishing, namely, psychological well-being (autonomy, competence, relatedness, learning, meaning and purpose, and engagement), emotional well-being (positive and negative affect, and job satisfaction) and social wellbeing (social acceptance, social growth, social contribution, social coherence and social integration).

\section{Psychological well-being}

To flourish in the work context, employees need to experience positive feelings and functioning (psychological well-being) (Janse Van Rensburg, Rothmann, \& Diedericks, 2017). At work, psychological well-being consists of the distinct aspects of autonomy, competence, relatedness, learning, meaning and purpose, and engagement (Redelinghuys, Rothmann, \& Botha, 2019). To attain positive functioning and psychological health, it is important for employees to satisfy the psychological needs of autonomy, competence and relatedness (Deci \& Ryan, 2000). Autonomy is associated with the desire to feel volition and voluntariness in terms of one's behaviour and actions, whilst competence refers to the need to feel effective and experience mastery in a work environment. As competence can readily be thwarted by challenges and negative feedback in the work context, employees have a need to feel that they are able to perform their jobs effectively. Relatedness, which is considered a fundamental need, pertains to employees' innate need to feel socially connected, cared for and significant amongst others. Equally essential to this need is contributing to and giving oneself to others (Deci \& Ryan, 2000; Rothmann, 2013; Ryan \& Deci, 2017). Learning, meaning and purpose are also important facets of psychological well-being. Learning is progressive and improvement-focused in nature and employees experience learning when they continue to grow and develop in their jobs over time (Spreitzer, Lam, \& Fritz, 2010). Meaning and purpose refers to employee's subjective judgements regarding the personal significance, value, worth and purpose of their work. Employees who experience meaning and purpose care about what they are doing and feel that their work matters and is important and meaningful (Rothmann, 2013; Steger, Dik, \& Duffy, 2012). Engagement, as the last facet, refers to the psychological states and behaviours that employees bring into their work roles (Kahn, 1990). Engagement is expressed physically, cognitively and emotionally; engaged employees experience a positive workrelated state of mind and display vitality (energy, mental resilience and persistence) and dedication (sense of significance, enthusiasm and pride) (Schaufeli, Salanova, González-Romá, \& Bakker, 2002).

\section{Emotional well-being}

Emotional well-being refers to employees' perceptions regarding the job satisfaction and positive emotions they experience in the work context (Janse Van Rensburg et al., 2017; Redelinghuys et al., 2019; Rothmann, 2013). Considering a state that comprises both cognitive and affective components, job satisfaction is defined as an employee's attitude or evaluation; what they think and how they feel about their job or various aspects/facets of their job (Saari \& Judge, 2004; Spector, 1997). Job satisfaction can be assessed using the global approach, which entails obtaining an overall feeling about the job as a whole, or the facet approach, which entails determining an employee's satisfaction or dissatisfaction with an aspect, or part of a job such as the nature of the work and supervisory and co-worker relationships (Spector, 1997). Job satisfaction has been linked to improved performance and is highly correlated with life satisfaction, whereas job dissatisfaction leads to turnover, absenteeism and withdrawal behaviours such as late coming and grievances (Saari \& Judge, 2004). The other aspect that contributes to an employee's emotional well-being is positive emotions. Positive emotions, which include joy, interest, gratitude, hope, contentment and love, fuel psychological resilience, build enduring personal resources and act as solutions for negative emotions (Fredrickson, 2001; Janse Van Rensburg et al., 2017; Rothmann, 2013).

\section{Social well-being}

Social well-being is defined as the assessment of one's condition and functioning in society and entails appraising the quality of one's social health (Keyes, 1998). Although the literature has focused on well-being as being predominately a private phenomenon, Keyes (1998) was of the view that because life is social in nature and we are embedded in 
society, it is important to consider how social health contributes to optimal functioning (Westerhof \& Keyes, 2010). Influenced by the work of sociologists and social psychologists, Keyes (1998) proposed five indicators of social well-being which reflect an individual's optimal social functioning and positive social health (Westerhof \& Keyes, 2010). When applied to the work context, the indicators of social well-being are social acceptance (having a positive attitude towards others and acknowledging their diversity), social growth (belief in the potential, growth and development of colleagues, groups and organisations), social contribution (the feeling that one's actions add value and contribute to others and the organisation), social coherence (perceiving one's organisation and social life as meaningful and understandable) and social integration (experiencing a sense of relatedness, belonging, comfort and support from the organisation one works in) (Janse Van Rensburg et al., 2017; Redelinghuys et al., 2019; Rothmann, 2013). Rothmann (2013) emphasises that in the South African work context, social well-being is particularly important owing to the collectivist philosophy of $u b u n t u$.

Workplace flourishing provides a multidimensional perspective to understanding, assessing and promoting wellbehaviour (Rothmann, 2013; Wissing et al., 2020). Individuals who flourish learn and are engaged, they display happiness and satisfaction with their jobs, and they feel socially connected. As such, all the dimensions of the flourishing at work framework need to be considered to understand and promote the well-being of employees (Janse Van Rensburg et al., 2017; Wissing et al., 2020).

\section{Research design}

Guided by the perspectives of Heidegger, this study employed a hermeneutic phenomenological methodology (Horrigan-Kelly, Millar, \& Dowling, 2016). In hermeneutic phenomenology, in-depth understanding and sharing of human experience are obtained through interpretation to provide meaningful co-constructed knowledge of the research phenomenon (Beck, Martinsen, Birkelund, \& Poulsen, 2017; Davidsen, 2013; Dreyer \& Pederson, 2009; Egbert \& Sanden, 2020). Interpretation is multi-perspectival and derived from the research context, as well as the understanding and experience of both the researcher and the participants (Crowther, Ironside, Spence, \& Smythe, 2017). Knowledge of and exposure to the volunteering environment and the well-being theoretical framework influenced interpretations of the meaning that resides within the volunteer's work-life experiences of volunteering (Crowther et al., 2017; Dreyer \& Pederson, 2009). As interpretation leads to multiple meanings and in this study was based on 'insights that matter to us' (Crowther et al., 2017 , p. 827), the findings presented in this article represent one perspective of the research phenomenon and are based on a co-constructed understanding of the experiences and manifestations of volunteer well-being in a volunteering work context.

\section{Research setting}

This study was conducted at a faith-based NPO that operates in the Gauteng provincial health sector. The participants of the study are volunteers, who work for the NPO, which provides volunteer services to government-run hospitals in the province. The volunteers' main activities include providing spiritual care and counselling, as well as emotional, social, trauma and physical support for patients and their families in these government-run hospitals. This setting constitutes a unique tri-party relationship with challenges faced by the client (hospitals), the NPO and the volunteer. On the one hand, government-run hospitals in South Africa experience challenges such as inadequate human resources, shortage of medical equipment, long patient waiting times, poor service delivery and hygiene, and lack of cleanliness (Maphumulo \& Bhengu, 2019). On the other hand, the NPO functions from a non-profit perspective, having to rely on subsidised and donated resources. Moreover, the volunteers have to cope with personal, financial and resource constraints.

\section{Researcher roles}

The primary researcher is a lecturer and was involved in the NPO through a community service project. Her profession as an IO psychologist, her scientific interest in well-being in the workplace and observations during her community work of the volunteers' positive well-being and continued retention, despite their difficult personal circumstances and the challenging work context, prompted her to explore their well-being. The secondary researcher, an academic and psychologist registered with the Health Professions Council of South Africa (HPCSA), was interested in studying wellbeing in such a unique work context. All the interviews were conducted by the primary researcher.

\section{Sampling and participants}

Purposive sampling was employed (Ngulube \& Ngulube, 2017), focusing on participants who fit the definition of a formal volunteer and had volunteered at the NPO for a minimum period of 12 months. The services of formal volunteers are defined as voluntary, unpaid and dedicated to a specific cause over an extended period through a formal agency or organisation (Snyder \& Omoto, 2008). The NPO provides its services to eight hospitals in the Gauteng province and extended the invitation to participate in the study to formal volunteers in this context. The richness and depth of the data dictated the sample size (Ngulube \& Ngulube, 2017; Thorne, 2016). After having conducted interviews with eight participants from four hospitals in Gauteng province no new themes emerged, and the richness of the data was ensured by follow-up interviews. In this way, data saturation was achieved (Thorne, 2016) and a sample size of eight was retained. The volunteers who participated in this study come from low-income living conditions and the majority were all formally unemployed. Being socio-economically disadvantaged themselves distinguishes the volunteers in this study from 
TABLE 1: Demographic profile of research participants.

\begin{tabular}{llll}
\multicolumn{4}{l}{ TABLE 1: Demographic profile of research participants. } \\
\hline Participant number & Gender & Age & Ethnicity \\
\hline PR1 & Female & 34 & Black person \\
PR2 & Female & 54 & White person \\
PR3 & Male & 61 & Black person \\
PR4 & Male & 58 & White person \\
PR5 & Female & 42 & Black person \\
PR6 & Male & 60 & Black person \\
PR7 & Female & 58 & Black person \\
PR8 & Female & 53 & Black person \\
\hline & & &
\end{tabular}

those in first world countries such as the United States of America (USA) and Europe (Kiyange, 2018; Niyimbanira \& Krugell, 2017). A demographic profile of the participants, which includes their allocated pseudonym (for confidentiality and anonymity purposes), gender, age and ethnicity, is provided in Table 1.

\section{Data collection}

Data were collected through in-depth unstructured interviews, following an informal conversational style. The aim of the interview was to elicit narratives of the lived work-life experiences of volunteers (Lauterbach, 2018; Yin, 2016). An open-ended question initiated the discussion with the participants, such as 'Can you tell me about your experiences of being a volunteer?' or 'How did it come about that you started volunteering?'. As the conversation developed, probing and follow-up questions such as 'How did that make you feel?', 'Can you give me an example?' focused on obtaining clarification on thoughts and feelings, and expanding on a particular issue, thus enabling in-depth exploration of the participants' narratives (Dahlberg, Dahlberg, \& Nyström, 2008). Direct and leading questions were avoided (Laverty, 2003) thus allowing for the research phenomenon to emerge naturally from the volunteers' lived experiences (Yeung, 2004). Interviews ranged between 60 min and $90 \mathrm{~min}$ and were tape-recorded and transcribed by a professional transcriber.

\section{Data analysis}

The data obtained were analysed using theoretical thematic analysis (Braun \& Clarke, 2006; Clarke \& Braun, 2017). Interpretations were related to the theoretical framework of flourishing at work. Analysis started by becoming familiarised with the data by actively reading the transcripts several times and making notes of initial thoughts and ideas. The second stage involved producing initial codes by identifying and naming sections of meaningful text. Next, the codes were sorted and collated into potential sub-themes and themes. A review and refining of the themes followed. The potential themes were reviewed by investigating the data within them to establish their relevance to that theme. The themes were also reviewed to determine whether they appropriately represented an understanding of the data as a whole. Lastly, the themes were refined by naming and conceptualising them to reflect the essence of their meaning (Braun \& Clarke, 2006; Clarke \& Braun, 2017).

\section{Strategies employed to ensure data quality and integrity}

Rigour and trustworthiness form an integral part of qualitative research (Given, 2016). Rigour in this study was sought by applying the criteria of credibility, transferability, dependability and confirmability (Ravitch \& Carl, 2019). These criteria were achieved by employing several techniques including providing a detailed audit trail of the research process, describing the research context, purposive sampling, peer review and debriefing, providing direct quotations to support the interpretations of the data and addressing the role played by the researchers by making experiential and theoretical preconceptions transparent and acknowledging their role in the research process.

\section{Reporting style}

In line with hermeneutic phenomenology and qualitative research, the findings are presented in a narrative format. Interpretations are expressed using rich and descriptive explanations supported by verbatim excerpts to remain faithful to participants' lived experience.

\section{Findings}

Guided by the meta-theoretical perspective of flourishing at work, four themes were constructed to describe how volunteer well-being manifests in the context of this study. Well-being is evident in the way volunteers experienced personal growth, in an engaged state of mind, in the emotional well-being they displayed in the workplace and in their social connectedness.

\section{'I am not so bad' ... Learning and growing in competence}

Despite being confronted by a new role and its associated challenges, the volunteers reported how they experience personal growth on different levels of the self. They related how their self-confidence had increased through positive work experiences, how they felt increasingly self-efficacious and ultimately experienced enhanced self-esteem. The personal growth of PR4 is evident in the way he narrates his initial self-doubt in the context of voluntary work. Yet, positive encounters with the patients banished these doubts and his confidence grew:

\footnotetext{
'... you grow in confidence as the time goes by and you see no but people are comfortable, you know, they, I saw they are comfortable with me, and because I am a listener rather than a talker, you know. So, and then I saw that people appreciate it, you know, when you sit down and you show interest in them and afterwards you, you know, they say thank you very much and that gives you confidence for the next week.' (PR4, M, 58)
}

As a psychiatric nurse, PR6 related his learning and growth in gaining spiritual experience and thought it was a valuable addition to his medical background. For him, learning how to apply his beliefs in the volunteering context, over and above his medical knowledge, helped him not only to 
reconcile the internal doubts he felt but also to build his selfefficacy. His self-confidence and volunteering self-efficacy grew as he experienced the fruit of his labour:

'What is beneficial about the volunteer work is that what you get from it is the practical aspect and the experience, you know sometimes praying for somebody, laying hands on them and seeing them recover.' (PR6, M, 60)

Whilst engaging in volunteering, PR4 emphasised spiritual growth more pertinently; yet, as with PR6, this growth was experienced in relation to eliminating self-doubt and growing in self-efficacy as a volunteer:

'When I get days that I am not, that I am doubting or just feel a bit down, you know, then I can sort of look back to the times when I saw other people and see the difference that God made in their lives.' (PR4, M, 58)

For PR4, this ability to reflect on his past experiences as a volunteer diminished the doubts that his volunteer work was not good enough. He felt strengthened not only in his competence but in his belief that God strengthens him and his clients:

'Well it strengthened my view of God you know, it strengthens my view ... So it helps me in my own life, you know, and also, in their time of distress and, you know, feeling helpless and that kind of things.' (PR4, M, 58)

The sense of personal growth experienced in the volunteering context is also seen in a growing self-esteem, for example PR2 relates how her sense of self has changed for the better:

'Yes, it makes a big change in my life as I can tell you this how I am feeling. I see it in my eye, in my - hoe ek dit sien né, is dat ek maak [how I see it is that I make], we make more time for somebody else and it makes me grow inside and when I feel down, and I can say, "I am not so bad."' (PR2, F, 54)

Personal growth is reflected in the way the volunteers gain self-confidence through positive work experiences and how they feel strengthened spiritually to believe that they can do this work. From this personal growth, volunteers learn what internal and spiritual resources they can rely on and they feel more confident about their ability to do volunteer work as described by PR1:

'So, sometimes when things like this are happening, I just ask God to help me how to come out of this or how to solve this. I must listen to the inner person, what does she tells me to do.' (PR1, F, 34)

Helping the hospital patients reflects a learning process which nurtures a more favourable view of the self in the volunteers, reflecting enhanced self-esteem. These personal growth experiences, in terms of increasing self-confidence, volunteer self-efficacy and self-esteem, relate to the psychological well-being constructs of learning and competence. By volunteering, the volunteers learn, progressively improving themselves through their experiences and, as their competence grows, they feel more effective and self-efficacious in this work context.

\section{'I will not stop' ... demonstrating an engaged state of mind}

The volunteers displayed an engaged affective-cognitive state of mind in the workplace which is reflected in the vigour and dedication they expressed despite taxing personal and work circumstances. This state of mind represents their general attitude, connection and approach to the work role of volunteering. Vigour, which is characterised by a willingness to persist and persevere despite obstacles, challenges and difficulties, is apparent in the way the volunteers continuously but positively and with fortitude navigated contextual and personal challenges. Despite, for example, being challenged emotionally by disheartened patients and abrasive doctors, PR2 demonstrates energy and vitality in emphasising her responsibility and commitment to remain positive and constructive:

'There are very negative patients ... they wait for the theatre and they say don't eat and they didn't eat for one, two, three, four days ... then the doctor is not nice to me, the doctor don't tell me - and then you sit and you must make it positive. You must take the negative out and you must make it positive for the patient.' (PR2, F, 54)

Volunteers are also challenged by a lack of resources such as insufficient parking on the hospital premises. This challenge is exacerbated by their own health problems, yet PR2 persisted in her dedication to go to work:

'The parking is a big problem for us, you know. But XXX help us to park here, but it is very far to walk for my back and my knee operation, but I do this with $\mathrm{XXX}$, we wait for her together and walk together, but it is very far.' (PR2, F, 54)

Other contextual challenges include fear of the constant exposure to viruses:

'... because it is sick people, you can get a virus.' (PR2, F, 54)

Personal challenges encompass, for example, financial constraints:

'... sometimes I have not got the money for the taxi and then I walk with my foot to go to the hospital.' (PR7, F, 58)

The volunteers persevere, however, and remain dedicated to continuing to volunteer:

'I must walk, I must pray for them, I cannot, I cannot go because the ward is stinky, no, it is human being, they must get healed, they must be comforted.' (PR7, F, 58)

PR3 also demonstrated dedication in the face of potential obstacles:

'Ai, by the way, so and so in that ward doesn't need me. But I am going there. You surprise that you go and say I am going there, let that person say whatever they want to say.' (PR3, M, 61)

PR6 plainly said:

'I am a volunteer at XXX hospital ... I am devoted, I am committed.' (PR6, M, 60) 
The volunteers' vigour is complemented by their dedication which is reflected in their commitment and the significance they attribute to the work role of volunteering. The extent of the volunteers' dedication is apparent in the emotional words of PR8:

'I will not stop to volunteer; as long as I am still here on earth I can do some, because I cannot stop.' (PR8, F, 53)

The significance of volunteer work for the volunteers is evident from the way they feel when being absent from the work environment:

'There are times that you can have the edge and then think of the tight schedule that you have. There are times when I cannot come on Tuesdays and I feel pain if I cannot come on Tuesday.' (PR3, M, 61)

These words of PR3 reflect the emotional connotation and investment they portray regarding volunteering.

\section{'I'm happy' ... exhibiting emotional well-being}

The volunteers spoke about how volunteering provides them with job satisfaction and elicits positive feelings in them such as happiness, hope and gratitude. PR6 described his job satisfaction as specifically related to the patients' reactions to his services:

'You get this person, you come to them, they are depressed, and the minute you say you love them they glow, they radiate from the face and their countenance change. So, you can see it is very therapeutic, those are the things that give me job satisfaction, those are the things that make me to continue doing this.' (PR6, M, 60)

For PR3, volunteering enabled him to satisfy a personal desire to help others; in turn, his job satisfaction extended to feeling content and positive about his whole life:

'... after helping with what I can then I feel peace, and then I am able to sort of you know enjoy life.' (PR3, M, 61)

PR3's words also relate to a range of positive feelings such as happiness, enjoyment, hope and gratitude experienced by the volunteers in the context of their work role. For PR5, her happiness stemmed from reaffirming her faith in the work context:

'I'm happy because I am doing God's work.' (PR5, F, 42)

For PR8 helping the needy: '[v]olunteering makes me happy because you help another people.' (PR8, F, 53)

In addition to feeling happy, more exhilarated feelings are experienced, which are described by PR3:

'“I feel my blessings you know, my thrills and so on after helping with anything thing that I could." Overall, volunteering is experienced as being an enjoyable work role: I enjoy it, I enjoy it, I enjoy volunteer work, it is so rewarding.' (PR3, M, 61)

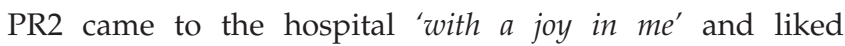
volunteering because of the variety it offers:
'... every day it is nice to come back, because it is not, two days is not the same or two patients is not the same.' (PR2, F, 54)

PR5 spoke about the loss of positive affect when she was not able to go to work:

'... when I am not going to the hospital, my heart is not good.' (PR5, F, 42)

The volunteers' narratives further revealed experiences of hope and gratitude. Despite the challenges present in the work environment, the volunteers felt hopeful that these challenges could be resolved and that there was a positive future for the patients:

'... there is hope, you know, sometimes you see a patient and yoh, will this patient ever experience better health again, you know, and then maybe one day you will see him here when you come to one of the clinics, after he has been discharged, and you see yoh it is a different person that you see now, you know, and you realise it, there is really hope, there is really hope.' (PR4, M, 58)

Religiously-rooted gratitude is expressed for the positive encounters the volunteers have with patients:

'... there is lots of patients that I can tell you, but this one was for me so special, but I didn't take her name and her number because you know it was for me so special and when I go out, I come to my car and I thank God for every patient.' (PR2, F, 54)

and for making a meaningful contribution to the patients' lives:

'When I wake up in the morning, I say thank you to God that I can do a difference for somebody else.' (PR2, F, 54)

Similarly, PR1 recounts a positive testimony from a patient and emphasises her gratitude:

'... we thank God.' (PR1, F, 34)

Volunteers demonstrated their emotional well-being in the volunteering context in their reported work and life satisfaction and in the positive emotions they recounted.

\section{'We are a family' ... feeling socially integrated and connected}

Volunteers spoke of their connection to the organisation in a way that reflected their sense of feeling supported by and belonging to the group of volunteers that provide their services to the NPO. Support, belonging, feeling cared about and valued characterise the quality of the volunteers' relationship with one another. Speaking about the other volunteers, PR2 referred to them as her new family: '... we are a family; new family and God give me a new family'. The positive relationships that have been built between the volunteers are revealed by PR4, implying a sense of belonging and connectedness:

'... what also means a lot to me is our group of volunteers, you know. To share and, so that means a lot to me, you know, because afterwards, after we are finished in the wards, we go to the tearoom there and, on an informal basis we share, and we become spiritual friends.' (PR4, M, 58) 
The volunteers' support and care for one another is further reflected in the story of PR2 who remembers how the other volunteers made her feel special (cared for and valued) during her knee-replacement:

\footnotetext{
'... what made me special that you volunteers, ons span [our team] came and visited me. And I cannot walk you know, the knee replacement was very sore and I was seven days in the ICU and XXX come and visit me in the ICU and XXX and XXX ... and they said "because you are special for me" and I was crying and I say, “God, I am really special."” (PR2, F, 54)
}

This theme illustrates the positive and intimate relationships that have been formed between the volunteers and demonstrates an approach that is rooted in valuing each other and in feeling a special connectedness. The volunteers' sense of belonging in this work context is further highlighted by their sense that they add value to the hospital staff and contribute to the patients' needs. At times the nurses ask the volunteers to pray for them:

'... that nurses, they say pray for us because this work is too hard for us.' (PR8, F, 53)

PR7 described how she felt valued by the patients because of the appreciation they expressed towards the volunteers:

'The mommy of the little babies, they are welcoming us, and then they said last week mama you were here, and I got healed, now the Doctor said two weeks, three days, four days I am going home. It is nice so.' (PR7, F, 58)

By volunteering, the volunteers enhance their social wellbeing and through their work experiences, they feel connected to each other, the patients and the workplace.

\section{Discussion}

The objective of this study was to develop a deeper understanding of how volunteer well-being manifests. The context of the study focused on volunteers who deliver their services consistently over an extended period, despite their financial and resource constraints and the emotionally taxing hospital environment they operate in. Such contextual challenges are said to potentially moderate the well-being effects of volunteering, as they may heighten volunteers' stress and burnout (Crook et al., 2006; Fuertes \& Jiménez, 2000). The findings of this study portray and conceptualise volunteer well-being as a positive phenomenon despite the contextual challenges the volunteers face and demonstrate how the participants flourish in this work context. Volunteers' flourishing is evident in the way their sense of competence is enhanced through personal growth and learning as well as in the way they demonstrate engagement, which are both aspects of psychological well-being. Flourishing is further evident in their emotional well-being, exhibited in positive emotions and job satisfaction. Lastly, volunteer well-being manifests as social well-being, that is in the way they feel connected and valued in this volunteering context. The findings therefore correspond with volunteering research which highlights the internal well-being benefits that volunteers derive from volunteer work such as personal growth, life satisfaction and social connectedness (see Andersson \& Öhlén, 2005; Casiday, Kinsman, Fisher, \& Bambra, 2008; Low, Butt, Paine, \& Smith, 2007).

The participants' flourishing is firstly apparent in the way they felt more self-confident and self-efficacious in their ability to service the hospital patients. Volunteering also enhances their self-esteem in that they increasingly realise their own worth. Such personal growth is conceptually related to competence, which, as a component of psychological well-being, refers to feelings of personal mastery and efficacy in the work environment (Deci \& Ryan, 2000). For optimal functioning and flourishing to manifest, individuals need to experience personal growth (Ryff, 1989) and a sense of competence (Deci \& Ryan, 2000). Volunteering provides the volunteers with opportunities for self-enhancement (learning) and affirmation of their value (self-esteem) and ability (self-efficacy) to do this work. The volunteers' narratives of personal growth correspond with the existing theory that suggests, continuous development in the face of new challenges and experiences are associated with higher levels of well-being and lower levels of distress (Ivtzan, Chan, Gardner, \& Prashar, 2013).

Flourishing was secondly also evident in the passion and dedication with which participants spoke about their work. The physical and emotional connectedness they expressed towards volunteering as a work role (Kahn, 1990; Schaufeli et al., 2002) echoes engagement as a sub-component of psychological well-being in the flourishing at work framework (Rothmann, 2013). Engagement is displayed through vitality (energy, resilience and persistence) as well as in dedication (sense of significance, enthusiasm and pride) (Schaufeli et al., 2002). The narratives portray the volunteers as being passionate, energetic and committed to volunteer work, despite the personal and contextual challenges they experience on a day-to-day basis. These results are congruent with studies showing that volunteer engagement takes on a similar structure to that of paid employees and the volunteers tend to experience high levels of engagement (Vecina, Chacón, Sueiro, \& Barrón, 2012). This physical, cognitive and emotional investment of the self in volunteer work reflects how the volunteers are positively oriented towards their work role and this enables them to persevere, confidently meet challenges and cope resiliently with experiences of adversity.

The participants' flourishing is demonstrated in the third theme, which reflects the feeling-well facet of flourishing (emotional well-being) that the volunteers experience. Volunteer work appears to be an important source of emotional well-being for them and promotes job satisfaction and positive emotional responses such as hope, gratitude and happiness. In the absence of financial rewards, job satisfaction and positive emotions are considered an important way to sustain the desire to volunteer (Boezeman \& Ellemers, 2009; Jiménez \& Fuertes, 2005). Serving as indicators of optimal well-being 
(Fredrickson, 2001), positive emotions are further viewed as critical ingredients that enable individuals to flourish and grow psychologically (Rothmann, 2013). This implies a reciprocal effect between the psychological and emotional well-being facets of flourishing.

Studies have shown that volunteering enhances social wellbeing (Son \& Wilson, 2012). From the findings it is proposed in the fourth theme that social well-being manifests because the participants reported a sense of social connection and belonging with significant others, as well as being valued for the contribution they make to others. The importance and benefits of employees' social health are evident in several models that include positive relationships as an aspect of flourishing (e.g. Huppert \& So, 2013; Keyes, 2002; Noble \& McGrath, 2015; Seligman, 2011). Volunteers' social integration and connectedness reflect their embeddedness in supportive social networks and highlight the crucial role played by social processes in the volunteering work context.

The findings demonstrate the manifestation of the well-being of volunteers as a multidimensional and dynamic phenomena consisting of feeling well and functioning well dimensions (cf. Janse Van Rensburg et al., 2017; Wissing et al., 2020). Their well-being is described as dynamic because these facets seem to build on and mutually affect one another. For example, it appears that when volunteers experience less emotional well-being (e.g. 'feeling down' - PR2 and PR6), they are able to rely on psychological well-being facets to become resilient and maintain their volunteering interest, dedication and effort. When their own psychological well-being resources run low (e.g. PR2 and PR4), they rely on their social wellbeing to sustain them.

\section{Implications}

The significance of volunteering is affirmed by the contribution that volunteers make to the cultural, political and economic spheres of society (Laverie \& McDonald, 2007; Oppenheimer, 2008). As such, much research is dedicated to identifying what motivates volunteers to continue volunteering and some have pointed to the positive effect volunteering has on the volunteers' well-being. The findings of this study offer valuable insight to NPOs, emphasising a focus on volunteer well-being to retain this valuable workforce, but also to sustain their psychological resilience under challenging work circumstances. Limited developmental resources are spent on volunteers in the context of non-profit functioning because such resources are rather directed at full-time employees. Yet, considering the importance of well-being, NPOs should partner with the health care institutions that they are servicing to consider contextual interventions that focus on both feeling and functioning well aspects to sustain and enhance the wellbeing of volunteers. Such interventions should focus on programmes that facilitate continuous self-development and growth, acknowledge and promote engagement, and enhance and build positive social networks and relations in a volunteering work context.
A recent study comparing cross-national differences in volunteer well-being highlighted the possibility of moderating factors in low-income contexts that have not been adequately considered in mainstream volunteer well-being research. The authors suggest that regular volunteering is detrimental to well-being when volunteers do not have access to generous unemployment benefits (Kamerāde \& Bennett, 2018). The limited logistical and financial resources of many South African volunteers may be a case in point. Therefore, even though the context of this study and its findings demonstrate how volunteers flourish despite their difficult circumstances, Kamerāde and Bennett's (2018) word of caution rings true. Personal growth and competence, engagement, job satisfaction and positive emotions, as well as social integration and value, represent the intrinsic motivational factors that influence volunteers' prolonged labour in the volunteering context. It is the reciprocal social responsibility of NPOs as well as the hospitals they serve to not only rely on volunteers' intrinsic motivation, but to build on it through relevant intervention and investment in this important human resource. Knowing what makes volunteers perform well (from this study, for example) provides insight into their motivation and focusing on these well-being dimensions will constitute targeted strategies to enhance and sustain volunteer well-being. Moreover, the socio-economic constraints of these voluntary workers render them a vulnerable population, and their wellbeing should not only be addressed by focusing on motivational factors, but by providing them financial support (in the form of a stipend) and other pragmatic resources, such as transport assistance and the wherewithal to maintain good personal hygiene, as an investment in the motivational factors suggested here.

\section{Limitations and recommendations}

Although this study offers in-depth insight and understanding of how volunteer well-being manifests, it is limited in the extent to which all facets of flourishing have been reported on. Owing to the limited scope of the article format and the need to ensure rigour in the discussion of the findings, some aspects in the flourishing of volunteers may have been overlooked in favour of the ones presented. The findings, however, offer foundational insight and highlight the importance of understanding volunteer well-being to enable the enhancement thereof. Further research is recommended to consolidate intervention design in the aspects of wellbeing that needs to be nurtured. Another limitation to be acknowledged is the religious context of the NPO that may not be reflective of the contexts within which all volunteering is conducted in South Africa. However, the findings contribute to an understanding of what motivates, sustains and retains volunteers in low-income, resource-constrained and faith-based settings. Lastly, interpretations were influenced by a specific theoretical framework and offer just one perspective of the research phenomenon which contributes to the existing body of knowledge. The possibility of alternative interpretations, however, provides scope for continued research which could adopt different theoretical perspectives. Future research could also explore the sources 
of volunteer well-being and the possible interventions that NPOs can use to promote volunteer well-being using other volunteer contexts.

\section{Conclusion}

Drawing on the work-life experiences of volunteers, this study facilitated an understanding of how volunteer well-being manifests. Volunteer well-being manifests in a sense of growing competence, an engaged work orientation, job satisfaction and positive affect, as well as feeling socially integrated and valued in the workplace. As such, volunteers flourish because they experience the multidimensional facets of psychological, emotional and social well-being in the volunteering context. Enhancing their well-being therefore should entail a multidimensional approach working dynamically on all three levels of well-being. Volunteers should not be left to their own internal psychological resources to sustain their well-being. Characterised by a unique work context, NPOs should invest in the well-being of volunteers by developing appropriate context-specific programmes aimed at capitalising on the unique manifestations of volunteer well-being. Volunteers with high levels of well-being may be better retained and could continue to contribute positively to the success of NPOs.

\section{Acknowledgements}

The authors would like to acknowledge and thank the NPO for allowing them to conduct this research study and the volunteers for sharing their stories.

\section{Competing interests}

The authors declare that they have no financial or personal relationships that may have inappropriately influenced them in writing this article.

\section{Author's contributions}

This article is based on the thesis of Aleksandra Furtak, University of South Africa (UNISA) in fulfilment of the requirements for her Doctor of Philosophy degree in Psychology and Antoni Barnard (UNISA) is the project supervisor. The authors collaboratively conceptualised the research project. A.F wrote the original draft of this article and was responsible for the literature review, data gathering and findings. A.B. contributed to the methodology, data analysis, writing and review of this article.

\section{Ethical consideration}

Ethical approval to conduct the study was obtained from the Research Ethics Committee of the University of South Africa (2015/CEMS/IOP/050). Written authorisation to conduct the study was obtained from the management of the NPO. Once consent to conduct the study had been received, the NPO volunteer coordinator acted as the gatekeeper, establishing contact between the primary researcher and suitable participants who fitted the inclusion criteria. Prior to the interviews, all participants consented in writing to participate in the study.

\section{Funding information}

This research received no specific grant from any funding agency in the public, commercial or not-for-profit sectors.

\section{Data availability statement}

The authors confirm that the data supporting the findings of this study are available within the article.

\section{Disclaimer}

The views and opinions expressed in this article are those of the authors and do not necessarily reflect the official policy or position of any affiliated agency of the authors.

\section{References}

Andersson, B., \& Öhlén, J. (2005). Being a hospice volunteer. Palliative Medicine, 19(8), 602-609. https://doi.org/10.1191/0269216305pm1083oa

Barnard, A., \& Furtak, A. (2020). Psychological resilience of volunteers in a South African health care context: A salutogenic approach and hermeneutic phenomenological inquiry. International Journal of Environmental Research and Public Health, 17(8), 2922. https://doi.org/10.3390/ijerph17082922

Beck, M., Martinsen, B., Birkelund, R., \& Poulsen, I. (2017). Raising a beautiful swan: A phenomenological-hermeneutic interpretation of health professionals' experiences of participating in a mealtime intervention inspired by protected mealtimes. International Journal of Qualitative Studies on Health and Well-Being, 12(1), a1360699. https://doi.org/10.1080/17482631.2017.1360699

Black, W., \& Living, R. (2004). Volunteerism as an occupation and its relationship to health and wellbeing. British Journal of Occupational Therapy, 67(12), 526-532. https://doi.org/10.1177/030802260406701202

Boezeman, E.J., \& Ellemers, N. (2009). Intrinsic need satisfaction and the job attitudes of volunteers versus employees working in a charitable volunteer organization. Journal of Occupational and Organizational Psychology, 82(4), 897-914. https:// doi.org/10.1348/096317908X383742

Braun, V., \& Clarke, V. (2006). Using thematic analysis in psychology. Qualitative Research in Psychology, 3(2), 77-101. https://doi.org/10.1191/1478088706 qp063oa

Brunier, G., Graydon, J., Rothman, B., Sherman, C., \& Liadsky, R. (2002). The psychological well-being of renal peer support volunteers. Journal of Advanced Nursing, 38(1), 40-49. https://doi.org/10.1046/j.1365-2648.2002.02144.x

Carter Kahl, S. (2019). Making the invisible visible: Capturing the multidimensional value of volunteerism to nonprofit organizations (Unpublished doctoral dissertation). University of San Diego, San Diego, CA.

Casiday, R., Kinsman, E., Fisher, C., \& Bambra, C. (2008). Volunteering and health What impact does it really have? London: Volunteering England.

Clarke, V., \& Braun, V. (2017). Thematic analysis. Journal of Positive Psychology, 12(3), 297-298. https://doi.org/10.1080/17439760.2016.1262613

Clary, E.G., Ridge, R.D., Stukas, A.A., Snyder, M., Copeland, J., Haugen, J., ... Miene, P. (1998). Understanding and assessing the motivations of volunteers: A functional approach. Journal of Personality and Social Psychology, 74(6), 1516-1530. https:// doi.org/10.1037/0022-3514.74.6.1516

Coetzee, M. (2019). Annual editorial overview 2019. SA Journal of Industrial Psychology/SA Tydskrif vir Bedryfsielkunde, 45, a1741. https://doi.org/10.4102/ sajip.v45i0.1741

Coetzer, W.J., \& Rothmann, S. (2007). A psychometric evaluation of measures of affective well-being in an insurance company. SA Journal of Industrial Psychology, 33(2), 7-15. https://doi.org/10.4102/sajip.v33i2.372

Cooper, C., \& Dewe, P. (2008). Well-being: Absenteeism, presenteeism, costs and challenges. Occupational Medicine, 58(8), 522-524. https://doi.org/10.1093/ occmed/kqn124

Crook, J., Weir, R., Willms, D., \& Egdorf, T. (2006). Experiences and benefits of volunteering in a community AIDS organization. Journal of the Association of Nurses in AIDS Care, 17(4), 39-45. https://doi.org/10.1016/j.jana.2006.05.002

Crowther, S., Ironside, P., Spence, D., \& Smythe, L. (2017). Crafting stories in hermeneutic phenomenology research: A methodological device. Qualitative Health Research, 27(6), 826-835. https://doi.org/10.1177/1049732316656161

Dahlberg, K., Dahlberg, H., \& Nyström, M. (2008). Reflective lifeworld research (2nd ed.). Lund: Studentlitteratur.

Davidsen, A.S. (2013). Phenomenological approaches in psychology and health sciences. Qualitative Research in Psychology, 10(3), 318-339. https://doi.org/10. 1080/14780887.2011.608466 
Deci, E.L., \& Ryan, R.M. (2000). The 'what' and 'why' of goal pursuits: Human needs and the self-determination of behavior. Psychological Inquiry, 11(4), 227-268. and the self-determination of behavior. Psych
https://doi.org/10.1207/S15327965PLI1104_01

Deci, E.L., \& Ryan, R.M. (2008). Hedonia, eudaimonia, and well-being: An introduction. Journal of Happiness Studies, 9(1), 1-11. https://doi.org/10.1007/s10902-0069018-1

Dreyer, P.S., \& Pedersen, B.D. (2009). Distanciation in Ricoeur's theory of interpretation Narrations in a study of life experiences of living with chronic illness and home mechanical ventilation. Nursing Inquiry, 16(1), 64-73. https://doi.org/ 10.1111/j.1440-1800.2009.00433.x

Egbert, J., \& Sanden, S. (2020). Foundations of educational research: Understanding theoretical components ( 2 nd ed.). New York, NY: Routledge.

Elias, J.K., Sudhir, P., \& Mehrotra, S. (2016). Long-term engagement in formal volunteering and well-being: An exploratory Indian study. Behavioral Sciences, 6(4), 1-15. https://doi.org/10.3390/bs6040020

Fallon, B.J., \& Rice, S.M. (2015). Investment in staff development within an emergency services organisation: Comparing future intention of volunteers and paid employees. The International Journal of Human Resource Management, 26(4) 485-500. https://doi.org/10.1080/09585192.2011.561222

Fleuret, S., \& Atkinson, S. (2007). Wellbeing, health and geography: A critical review and research agenda. New Zealand Geographer, 63(2), 106-118. https://doi. org/10.1111/j.1745-7939.2007.00093.x

Folwell, A., \& Kauer, T. (2018). 'You see a baby die and you're not fine': A case study of stress and coping strategies in volunteer emergency medical technicians. Journal of Applied Communication Research, 46(6), 723-743. https://doi.org/10.1080/00 909882.2018.1549745

Fredrickson, B.L. (2001). The role of positive emotions in positive psychology: The broaden-and-build theory of positive emotions. American Psychologist, 56(3), 218-226. https://doi.org/10.1037/0003-066X.56.3.218

Fuertes, F.C., \& Jiménez, M.L.V. (2000). Motivation and burnout in volunteerism. Psychology in Spain, 4(1), 75-81.

Garner, J.T., \& Garner, L.T. (2011). Volunteering an opinion: Organizational voice and volunteer retention in nonprofit organizations. Nonprofit and Voluntary Sector Quarterly, 40(5), 813-828. https://doi.org/10.1177/0899764010366181

Given, L.M. (2016). 100 questions (and answers) about qualitative research. Thousand Oaks, CA: Sage.

Haivas, S., Hofmans, J., \& Pepermans, R. (2013). Volunteer engagement and intention to quit from a self-determination theory perspective. Journal of Applied Social Psychology, 43(9), 1869-1880. https://doi.org/10.1111/jasp.12149

Handy, F., \& Mook, L. (2011). Volunteering and volunteers: Benefit-cost analyses Research on Social Work Practice, 21(4), 412-420. https://doi.org/10.1177/ 1049731510386625

Hao, Y. (2008). Productive activities and psychological well-being among older adults. Journal of Gerontology: Social Sciences, 63B(2), S64-S72. https://doi.org/10.1093/ geronb/63.2.564

Haski-Leventhal, D. (2009). Elderly volunteering and well-being: A cross-European comparison based on SHARE data. Voluntas: International Journal of Voluntary and Nonprofit Organizations, 20(4), 388-404. https://doi.org/10.1007/s11266009-9096-x

Haski-Leventhal, D., Hustinx, L., \& Handy, F. (2011). What money cannot buy: The distinctive and multidimensional impact of volunteers. Journal of Community Practice, 19(2), 138-158. https://doi.org/10.1080/10705422.2011.568930

Henderson, L.W., \& Knight, T. (2012). Integrating the hedonic and eudaimonic perspectives to more comprehensively understand wellbeing and pathways to wellbeing. International Journal of Wellbeing, 2(3), 196-221. https://doi.org/ 10.5502/ijw.v2.i3.3

Horrigan-Kelly, M., Millar, M., \& Dowling, M. (2016). Understanding the key tenets of Heidegger's philosophy for interpretive phenomenological research. International
Journal of Qualitative Methods, 15(1), 1-8. https://doi.org/10.1177/1609406 Journal of

Huppert, F.A., \& So, T.T. (2013). Flourishing across Europe: Application of a new conceptual framework for defining well-being. Social Indicators Research, 110(3) 837-861. https://doi.org/10.1007/s11205-011-9966-7

Huynh, J.Y., Metzer, J.C., \& Winefield, A.H. (2012). Engaged or connected? A perspective of the motivational pathway of the job demands-resources model in volunteers working for non-profit organizations. VOLUNTAS: International Journal of Voluntary and Nonprofit Organizations, 23(4), 870-898. https://doi. org/10.1007/s11266-011-9233-1

Ivtzan, I., Chan, C.P., Gardner, H.E., \& Prashar, K. (2013). Linking religion and spirituality with psychological well-being: Examining self-actualisation, meaning in life, and personal growth initiative. Journal of Religion and Health, 52(3), 915-929. https:// doi.org/10.1007/s10943-011-9540-2

Janse Van Rensburg, C., Rothmann, S.I., \& Diedericks, E. (2017). Person-environment fit, flourishing and intention to leave in universities of technology in South Africa. South African Journal of Industrial Psychology, 43(1), 1-10. https://doi. org/10.4102/sajip.v43i0.1422

Jiménez, M.L.V., \& Fuertes, F.C. (2005). Positive emotions in volunteerism. The Spanish Journal of Psychology, 8(1), 30-35. https://doi.org/10.1017/S1138741600004935

Kahn, W.A. (1990). Psychological conditions of personal engagement and disengagement at work. Academy of Management Journal, 33(4), 692-724. https://doi.org/10.2307/256287

Kamerāde, D., \& Bennett, M.R. (2018). Rewarding work: Cross-national differences in benefits, volunteering during unemployment, well-being and mental health Work, Employment and Society, 32(1), 38-56. https://doi.org/10.1177/095001 7016686030
Kashdan, T.B., Biswas-Diener, R., \& King, L.A. (2008). Reconsidering happiness: The costs of distinguishing between hedonics and eudaimonia. The Journal of Positive costs of distinguishing between hedonics and eudaimonia. The Journal of Posi
Psychology, 3(4), 219-233. https://doi.org/10.1080/17439760802303044

Keyes, C.L.M. (1998). Social well-being. Social Psychology Quarterly, 61(2), 121-140. https://doi.org/10.2307/2787065

Keyes, C.L.M. (2002). The mental health continuum: From languishing to flourishing in life. Journal of Health and Social Research, 43(2), 207-222. https://doi.org/ $10.2307 / 3090197$

Kheswa, J.G. (2019). Factors and effects of work-related stress and burnout on the well-being of social workers in the Eastern Cape province, South Africa. SA Journa of Industrial Psychology, 45(1), 1-10. https://doi.org/10.4102/sajip.v45i0.1661

Kiyange, F. (2018). Volunteering in hospice and palliative care in Africa. In R. Scott \& S. Howlett (Eds.), The changing face of volunteering in hospice and palliative care (pp. 142-156). Oxford: Oxford University Press.

Kowalski, T.H., \& Loretto, W. (2017). Well-being and HRM in the changing workplace. The International Journal of Human Resource Management, 28(16), 2229-2255. The International Journal of Human Resource Man
https://doi.org/10.1080/09585192.2017.1345205

Kun, A., \& Gadanecz, P. (2019). Workplace happiness, well-being and their relationship with psychological capital: A study of Hungarian teachers. Current Psychology, December, 1-15. https://doi.org/10.1007/s12144-019-00550-0

La Placa, V., McNaught, A., \& Knight, A. (2013). Discourse on wellbeing in research and practice. International Journal of Wellbeing, 3(1), 116-125. https://doi. org/10.5502/ijw.v3i1.7

Lauterbach, A.A. (2018). Hermeneutic phenomenological interviewing: Going beyond semi-structured formats to help participants revisit experience. The Qualitative Report, 23(11), 2883-2898.

Laverie, D.A., \& McDonald, R.E. (2007). Volunteer dedication: Understanding the role of identity importance on participation frequency. Journal of Macromarketing, 27(3), 274-288. https://doi.org/10.1177/0276146707302837

Laverty, S.M. (2003). Hermeneutic phenomenology and phenomenology: A comparison of historical and methodological considerations. International Journal of Qualitative Methods, 2(3), 1-29. https://doi.org/10.1177/160940690300200303

Lourens, G.M., \& Daniels-Felix, D.K. (2017). Hospital volunteerism as human resource solution: Motivation for both volunteers and the public health sector. SA Journal of Human Resource Management/SA Tydskrif vir Menslikehulpbronbestuur, 15, of Human Resource Management/SA Tydskrif vir
a813. https://doi.org/10.4102/sajhrm.v15i0.813

Low, N., Butt, S., Paine, A.E., \& Smith, J.D. (2007). Helping out: A national survey of volunteering and charitable giving. London: Cabinet Office.

Mackenzie, S., Baadjies, L., \& Seedat, M. (2015). A phenomenological study of volunteers' experiences in a South African waste management campaign. Voluntas: International Journal of Voluntary and Nonprofit Organization, 26(3), 756-776. https://doi.org/10.1007/s11266-014-9450-5

Manetti, G., Bellucci, M., Como, E., \& Bagnoli, L. (2015). Investing in volunteering Measuring social returns of volunteer recruitment, training and management. Voluntas: International Journal of Voluntary and Nonprofit Organizations, 26(5) 2104-2129. https://doi.org/10.1007/s11266-014-9497-3

Maphumulo, W.T., \& Bhengu, B.R. (2019). Challenges of quality improvement in the healthcare of South Africa post-apartheid: A critical review. Curationis, 42(1), 1-9. https://doi.org/10.4102/curationis.v42i1.1901

McMunn, A., Nazroo, J., Wahrendorf, M., Breeze, E., \& Zaninotto, P. (2009). Participation in socially-productive activities, reciprocity and wellbeing in later life: Baseline results in England. Ageing \& Society, 29(5), 765-782. https://doi. org/10.1017/S0144686X08008350

Mellor, D., Hayashi, Y., Firth, L., Stokes, M., Chambers, S., \& Cummins, R. (2008) Volunteering and well-being: Do self-esteem, optimism and perceived control
mediate the relationship? Journal of Social Service Research, 34(4), 61-70. mediate the relationship? Journal of Social
https://doi.org/10.1080/01488370802162483

Messias, D.K.H., De Jong, M.K., \& McLoughlin, K. (2005). Being involved and making a difference: Empowerment and well-being among women living in poverty. Journal difference: Empowerment and well-being among women living in poverty. Journ
of Holistic Nursing, 23(1), 70-88. https://doi.org/10.1177/0898010104272023

Morrow-Howell, N., Hinterlong, J., Rozario, P.A., \& Tang, F. (2003). Effects of volunteering on the well-being of older adults. Journal of Gerontology, 58(3), 137-145. https://doi.org/10.1093/geronb/58.3.S137

Newman, S., Vasudev, J., \& Onawola, R. (1985). Older volunteers' perceptions of impacts of volunteering on their psychological well-being. Journal of Applied Gerontology, 4(2), 123-127. https://doi.org/10.1177/073346488500400215

Ngulube, P., \& Ngulube, B. (2017). Application and contribution of hermeneutic and eidetic phenomenology to indigenous knowledge research. In P. Ngulube (Ed.), Handbook of research on theoretical perspectives on indigenous knowledge systems in developing countries (pp. 127-155). Hershey, PA: IGI Global.

Niyimbanira, F., \& Krugell, W. (2017). The characteristics of volunteers in South Africa. Journal of Economic and Financial Sciences, 10(3), 424-436.

Noble, T., \& McGrath, H. (2015). PROSPER: A new framework for positive education. Psychology of Well-being, 5(2), 1-17. https://doi.org/10.1186/s13612-015-0030-2

Oppenheimer, M. (2008). Volunteering: Why we can't survive without it. New South Wales: University of New South Wales Press.

Penner, L.A. (2002). Dispositional and organizational influences on sustained volunteerism: An interactionist perspective. Journal of Social Issues, 58(3), 447-467. https://doi.org/10.1111/1540-4560.00270

Ravitch, S.M., \& Carl, N.M. (2019). Qualitative research: Bridging the conceptual, theoretical, and methodological (2nd edn.). Thousand Oaks, CA: Sage.

Redelinghuys, K., Rothmann, S., \& Botha, E. (2019). Workplace flourishing: Measurement, antecedents and outcomes. SA Journal of Industrial Psychology/SA Tydskrif vir Bedryfsielkunde, 45, a1549. https://doi.org/10.4102/sajip.v45i0.1549 
Roemer, A., \& Harris, C. (2018). Perceived organisational support and well-being: The role of psychological capital as a mediator. SA Journal of Industrial Psychology, 44(1), 1-11. https://doi.org/10.4102/sajip.v44i0.1539

Rothmann, S. (2013). From happiness to flourishing at work: A Southern African perspective In M.P. Wissing (Ed.), Well-being research in South Africa: Crosscultural advances in positive psychology (Vol. 4, pp. 123-151). Dordrecht: Springer.

Rothmann, S., \& Malan, M. (2011). Work-related well-being of South African hospital pharmacists. SA Journal of Industrial Psychology, 37(1), 1-11. https://doi. org/10.4102/sajip.v37i1.895

Russell, A.R., Nyame-Mensah, A., De Wit, A., \& Handy, F. (2018). Volunteering and wellbeing among ageing adults: A longitudinal analysis. Voluntas: International Journal of Voluntary and Nonprofit Organizations, 30, 1-14. https://doi.org/ 10.1007/s11266-018-0041-8

Ryan, R.M., \& Deci, E.L. (2017). Self-determination theory: Basic psychological needs in motivation, development, and wellness. New York, NY: The Guilford Press.

Ryan, R.M., Huta, V., \& Deci, E.L. (2008). Living well: A self-determination theory perspective on eudaimonia. Journal of Happiness Studies, 9(1), 139-170. https:// doi.org/10.1007/s10902-006-9023-4

Ryff, C.D. (1989). Happiness is everything, or is it? Explorations on the meaning of psychological well-being. Journal of Personality and Social Psychology, 57(6), 1069-1081. https://doi.org/10.1037/0022-3514.57.6.1069

Saari, L.M., \& Judge, T.A. (2004). Employee attitudes and job satisfaction. Human Resource Management, 43(4), 395-407. https://doi.org/10.1002/hrm.20032

Schaufeli, W.B., Salanova, M., González-Romá, V., \& Bakker, A.B. (2002). The measurement of engagement and burnout: A two sample confirmatory facto analytic approach. Journal of Happiness Studies, 3(1), 71-92. https://doi.org/ 10.1023/A:1015630930326

Seligman, M.E.P. (2011). Flourish. New York, NY: Free Press.

Snyder, M., \& Omoto, A.M. (2008). Volunteerism: Social issues perspectives and socia policy implications. Social Issues and Policy Review, 2(1), 1-36. https://doi. org/10.1111/j.1751-2409.2008.00009.x

Son, J., \& Wilson, J. (2012). Volunteer work and hedonic, eudemonic, and social wellbeing. Sociological Forum, 27(3), 658-681. https://doi.org/10.1111/j.1573-7861. 2012.01340.x

Spector, P.E. (1997). Job satisfaction: Application, assessment, causes, and consequences. Thousand Oaks, CA: Sage.

Spreitzer, G.M., Lam, C.F., \& Fritz, C. (2010). Engagement and human thriving: Complimentary perspectives on energy and connections to work. In A.B. Bakker \& M.P. Leiter (Eds.), Work engagement: A handbook of essential theory and research (pp. 132-146). New York, NY: Psychology Press.

Steger, M.F., Dik, B.J., \& Duffy, R.D. (2012). Measuring meaningful work: The work and meaning inventory (WAMI). Journal of Career Assessment, 20(3), 322-337. https://doi.org/10.1177/1069072711436160
Tabassum, F., Mohan, J., \& Smith, P. (2016). Association of volunteering with mental well-being: A lifecourse analysis of a national population-based longitudinal study in the UK. BMJ Open, 6(8), e011327. https://doi.org/10.1136/bmjopenstudy in the

Theobald, T., \& Cooper, C. (2012). Doing the right thing: The importance of wellbeing in the workplace. London: Palgrave Macmillan.

Thoits, P.A., \& Hewitt, L.N. (2001). Volunteer work and well-being. Journal of Health and Social Behavior, 42(2), 115-131. https://doi.org/10.2307/3090173

Thorne, S. (2016). Interpretive description: Qualitative research for applied practice (2nd ed.). New York, NY: Routledge. https://doi.org/10.4324/9781315545196

Van Vuuren, L.J. (2010). Industrial psychology: Goodness of fit? Fit for goodness? SA Journal of Industrial Psychology/SA Tydskrif vir Bedryfsielkunde, 36(2), 1-16. https://doi.org/10.4102/sajip.v36i2.939

Van Willigen, M. (2000). Differential benefits of volunteering across the life course. Journal of Gerontology, 55(5), 308-318. https://doi.org/10.1093/geronb/ 55.5.S308

Vecina, M.L., Chacón, F., Sueiro, M., \& Barrón, A. (2012). Volunteer engagement: Does engagement predict the degree of satisfaction among new volunteers and the commitment of those who have been active longer? Applied Psychology, 61(1) 130-148. https://doi.org/10.1111/j.1464-0597.2011.00460.x

Vecina, M.L., \& Fernando, C. (2013). Volunteering and well-being: Is pleasure-based rather than pressure-based prosocial motivation that which is related to positive effects? Journal of Applied Social Psychology, 43(4), 870-878. https://doi. org/10.1111/jasp.12012

VSO \& RAISA. (2011). Volunteer management needs assessment among South African civil society organisations. Unpublished research report. Pretoria: Author. Retrieved from http://www.vosesa.org.za/sadcconference/papers/12.pdf

Westerhof, G.J., \& Keyes, C.L. (2010). Mental illness and mental health: The two continua model across the lifespan. Journal of Adult Development, 17(2), 110-119. https://doi.org/10.1007/s10804-009-9082-y

Windsor, T.D., Anstey, K.J., \& Rodgers, B. (2008). Volunteering and psychological wellbeing among young-old adults: How much is too much? The Gerontologist, 48(1) 59-70. https://doi.org/10.1093/geront/48.1.59

Wissing, M.P., Potgieter, J.C., Guse, T., Khumalo, I.P., \& Nel, L. (2020). Towards flourishing: Embracing well-being in diverse contexts (2nd ed.). Pretoria: Van Schaik.

Yeung, A.B. (2004). The octagon model of volunteer motivation: Results of a phenomenological analysis. Voluntas: International Journal of Voluntary and Nonprofit Organizations, 15(1), 21-46. https://doi.org/10.1023/B:VOLU.00000 23632.89728.ff

Yin, R.K. (2016). Qualitative research from start to finish (2nd ed.). New York, NY: The Guilford Press. 